\title{
Production of Ligninolytic Enzymes by White-Rot Fungus Datronia sp. KAPI0039 and Their Application for Reactive Dye Removal
}

\author{
Pilanee Vaithanomsat, ${ }^{1}$ Waraporn Apiwatanapiwat, ${ }^{1}$ Oncheera Petchoy, ${ }^{2}$ \\ and Jirawate Chedchant ${ }^{3}$ \\ ${ }^{1}$ Kasetsart Agricultural and Agro-Industrial Product Improvement Institute (KAPI), Kasetsart University, 50 Chatuchak, \\ Bangkok 10900, Thailand \\ ${ }^{2}$ College of Environment, Kasetsart University, 50, Phaholyothin Road, Chatuchak, Bangkok 10900, Thailand \\ ${ }^{3}$ Faculty of Agro-Industry, Kasetsart University, 50, Phaholyothin Road, Chatuchak, Bangkok 10900, Thailand
}

Correspondence should be addressed to Pilanee Vaithanomsat, p_vaithanomsat@yahoo.com

Received 4 December 2009; Accepted 25 June 2010

Academic Editor: Yves Andrès

Copyright (c) 2010 Pilanee Vaithanomsat et al. This is an open access article distributed under the Creative Commons Attribution License, which permits unrestricted use, distribution, and reproduction in any medium, provided the original work is properly cited.

This study focused on decolorization of 2 reactive dyes; Reactive Blue 19 (RBBR) and Reactive Black 5 (RB5), by selected white-rot fungus Datronia sp. KAPI0039. The effects of reactive dye concentration, fungal inoculum size as well as $\mathrm{pH}$ were studied. Samples were periodically collected for the measurement of color unit, Laccase (Lac), Manganese Peroxidase (MnP), and Lignin Peroxidase (LiP) activity. Eighty-six percent of $1,000 \mathrm{mg} \mathrm{L}^{-1} \mathrm{RBBR}$ decolorization was achieved by $2 \%(\mathrm{w} / \mathrm{v})$ Datronia sp. KAPI0039 at $\mathrm{pH}$ 5. The highest Lac activity $\left(759.81 \mathrm{UL}^{-1}\right.$ ) was detected in the optimal condition. For RB5, Datronia sp. KAPI0039 efficiently performed $\left(88.01 \%\right.$ decolorization) at $2 \%(\mathrm{w} / \mathrm{v})$ fungal inoculum size for the reduction of $600 \mathrm{mgL}^{-1} \mathrm{RB} 5 \mathrm{under} \mathrm{pH} 5$. The highest Lac activity (178.57 $\mathrm{UL}^{-1}$ ) was detected, whereas the activity of $\mathrm{MnP}$ and LiP was absent during this hour. The result, therefore, indicated that Datronia sp. KAPI0039 was obviously able to breakdown both reactive dyes, and Lac was considered as a major lignin-degradation enzyme in this reaction.

\section{Introduction}

Large amount of chemical dyes, approximately 10,000 different dyes and pigments per year, are used for various industrial applications such as textile and printing industries. It is estimated that about $10 \%$ are lost in industrial effluents [1]. As a result, a significant proportion of these dyes are released to the environment in wastewater. Moreover, these dyes are designed to be resistant to light, water, and oxidizing agents and therefore difficult to naturally degrade once released into aquatic systems [2]. Thus, this can cause the obstruction of sunlight pass through the water resource by synthetic dyes, then leading to the decrease in oxygen dissolved in water, the photosynthesis of water plants, and the biodegradation of organic matters. At present, the biotechnological approaches were proven to be potentially effective in treatment of this pollution source in an ecoefficient manner [2]. The possibility to use ligninolytic fungi for the removal of synthetic dyes is one approach that attracts considerable attention. This is due to their production of ligninolytic enzymes-most frequently laccase and manganese peroxidase-that enable these microorganisms to oxidize a broad range of substrates including synthetic dyes [3].

Many reports so far have demonstrated that whiterot fungi, such as Phanerochaete chrysosporium, Trametes versicolor, Pleurotus ostreatus, Ganoderma spp., Irpex lacteus, Dichomitus squalens, and Ischnoderma resinosum, in Basidiomycete class, were efficiently capable of decolorization of pulping effluent and dye solution by lignin-degrading enzymes (Lignin Peroxidase (LiP), Laccase (Lac), and Manganese Peroxidase $(\mathrm{MnP}))$ through the oxidation of phenolic 
group in dyes [4-8]. They have been also widely researched for their ability in degradation and adsorption of dyes and some toxic chemicals such as PAHs or chlorophenol compounds $[9,10]$. It was assumed that the color disappeared only after the chromophore structure of dye molecule was destroyed by many attack of lignin-degrading enzymes [11]. Attempts have still been made to screen for new strains with these capabilities. In 2006, Apiwattanapiwat et al. reported the efficiency of Datronia sp. KAPI0039 and Trichaptum sp. KAPI0025, isolated from rotten woods in Thailand, for $54.9 \%$ and $54.4 \%$ decolorization of pulp and paper mill effluent, respectively. In 2009, Chedchant et al. showed that Datronia sp. KAPI0039 that was cultivated on solid agar containing sawdust or rice straw released extracellular Lac and MnP. However, no research is conducted whether the decolorization capability of this strain is related to lignindegrading enzymes. The knowledge obtained from this research is not only important to the use of enzymes or microorganisms in control either synthetic dyes removal or lignin degradation, but also to the understanding as alternatives to the conventional treatments.

The present study aimed at enhancing the knowledge of white-rot fungus Datronia sp. KAPI0039 involved in the bio-oxidation of different reactive dyes. To this purpose, the relationship between ligninolytic enzymes production and decolorization of reactive dye solution by Datronia sp. KAPI0039 was assessed. Furthermore, its degradation efficiency for azo-based and anthraquinone-based reactive was compared.

\section{Materials and Methods}

2.1. Microorganism and Culture Conditions. A culture of white-rot fungus, Dratronia sp.KAPI0039, obtained from Apiwattanapiwat et al. [12], was used in this study. The fungal stock culture was maintained through periodic transfer on Potato Dextrose Agar (PDA) at $4^{\circ} \mathrm{C}$ until use. To prepare the inoculum, the fungus was transferred onto a fresh PDA plate and incubated at $30^{\circ} \mathrm{C}$ for 7 days. This was ready to be used for further experiments.

2.2. Dyes. The reactive dyes used in this study were obtained from DyStar Thai Company Limited in Thailand. They were Reactive Blue 19 (RBBR) and Reactive Black 5 (RB5). RBBR is a synthetic anthraquinone-based reactive dye. RB5 is a tetrasulphonated disazo reactive dye.

2.3. Bio-Oxidation of the Reactive Dye Solution by Dratronia sp.KAPI0039 (Adapted from [13]). Decolorization experiments were carried out in flasks. The dye solutions were prepared with the supplement of $(\mathrm{g} / \mathrm{L})$ : glucose 10.0; $\mathrm{K}_{2} \mathrm{HPO}_{4} 1.0 ; \mathrm{MgSO}_{4} \cdot 7 \mathrm{H}_{2} \mathrm{O} 0.5 ; \mathrm{KCl} \mathrm{0.5} ; \mathrm{FeSO}_{4} \cdot 7 \mathrm{H}_{2} \mathrm{O} 0.01$; $\mathrm{NH}_{4} \mathrm{NO}_{3}$ 1.75; and $\mathrm{pH}$ 5.5. To prepare inocula for liquid cultures, 20 agar plugs $(\phi 7 \mathrm{~mm}$ from the edge of a 7 day-old agar culture) of Dratronia sp.KAPI0039 growing mycelia were inoculated into $250 \mathrm{~mL}$ Glucose Yeast Extract (GYE) medium and then incubated with $150 \mathrm{rpm}$ shaking at $30^{\circ} \mathrm{C}$ for 6 days [12]. After that, they were filtered through cheese cloth to obtain fungal pellets. The bio-oxidation experiment was carried out in $500-\mathrm{mL}$ flasks containing $300 \mathrm{~mL}$ dye solution. These were inoculated with $2.5 \%(\mathrm{w} / \mathrm{v})$ wet Datronia sp. fungal pellets and incubated with $150 \mathrm{rpm}$ shaking at $30^{\circ} \mathrm{C}$ for 7 days. The color units and lignindegrading enzymes production were monitored periodically in order to evaluate the performance of fungal cells in decolorization. All treatments were run in triplicates. The related parameters, including the concentration of reactive dyes $(200,400,600,800$, and 1,000 mg/L), fungal inoculum size $(1,2$, and $3 \mathrm{~g})$, and $\mathrm{pH}(3,5,7$, and 9$)$ were studied.

2.4. Enzyme Activities. Laccase (Lac) activity was measured by monitoring the oxidation of 2,2'-azinobis(3ethylbenzothiazoline-6-sulfonic acid) (ABTS) at $420 \mathrm{~nm}$ (molar extinction coefficient $=36,000 \mathrm{M}^{-1} \mathrm{~cm}^{-1}$ ) according to Eggert et al.,1996. One unit of laccase activity was defined as the amount of enzyme that oxidizes one $1 \mu \mathrm{mol}$ ABTS in 1 minute.

Lignin peroxidase (LiP) activity was measured by monitoring the oxidation of veratryl alcohol in the presence of $\mathrm{H}_{2} \mathrm{O}_{2}$ at $310 \mathrm{~nm}$ (molar extinction coefficient = 9,300 $\mathrm{M}^{-1} \mathrm{~cm}^{-1}$ ) according to Tien and Kirk [14]. One unit of LiP activity was defined as the amount of enzyme catalyzing the formation of $1 \mu \mathrm{mol}$ of veratraldehyde per minute.

Determination of Manganese peroxidase ( $\mathrm{MnP}$ ) activity using MBTH and DMAB was based on Castillo et al., 1994. MBTH and DMAB were oxidatively coupled by the action of the enzyme in the presence of added $\mathrm{H}_{2} \mathrm{O}_{2}$ and $\mathrm{Mn}^{2+}$ ions to give a purple indamine dye product. One unit of $\mathrm{MnP}$ activity was defined as an amount catalyzing the production of $1 \mu \mathrm{mol}$ of green or purple product per $\mathrm{ml}$ per min.

2.5. Color Unit. The samples were filtered through $0.45 \mu \mathrm{m}$ cellulose acetate membrane to remove suspended solids. The intensity of color, before and after treatment, was spectrophotometrically determined (HUCH DR/2010) at $592 \mathrm{~nm}[3]$.

\section{Results and Discussion}

3.1. Activities of Lac, LiP, and MnP. The results showed the consistent result with Chedchant et al. [15] that Datronia sp. KAPI0039 produced Lac and MnP but not LiP. The activity of the enzymes, however, differed significantly (data not shown). Lac was detectable in the early growth period and reached maximum $(4,502.2 \mathrm{U} / \mathrm{g}$ substrate) after 4 days of cultivation. Unlikely, MnP activity was maximum (471.7 U/g substrate) after 8 day cultivations. However, none of LiP was detected.

\subsection{Biodegradation of the Reactive Dye Solution by Dratronia sp. KAPI0039}

3.2.1. The Effect of Reactive Dyes Concentrations. The effects of reactive RBBR and RB5 concentrations on \%decolorization, Lac and MnP activities by Datronia sp. 


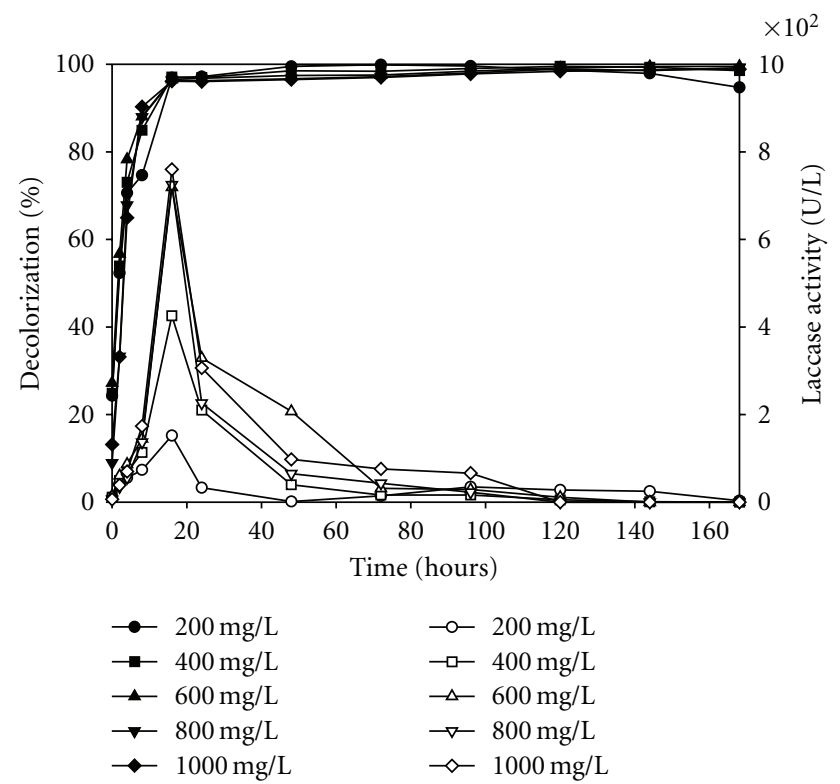

FIgURE 1: The effect of reactive RBBR dye concentrations on \%decolorization and Lac activity after cultivation with Datronia sp. KAPI0039; close symbol = \%decolorization; open symbol = Laccase activity.

KAPI0039 were experimented. Dye solutions were varied at $200,400,600,800$, and $1,000 \mathrm{mg} / \mathrm{L}$ concentrations. The results indicated a dramatic decrease $(>90 \%)$ in color reduction of both RBBR and RB5 solutions at every concentration (Figures 1 and 2, respectively). The results (99.6\% decolorization in 72 hours) also indicated the rate and extent of decolorization of RBBR compared favourably with those by other white-rot fungi such as P. chrysosporium (83\% decolorization in 264 hours; [16]), Bjerkandera sp. BOS55 (65\% decolorization in 480 hours; [16]), and Trametes trogii (85\% decolorization in 72 hours; Mechichi et al., 2006 [17]). Furthermore, the result demonstrated that dye concentration did affect the time period to reach maximum decolorization for both RBBR and RB5 solutions. A general tendency was that more concentrated dye solution caused slower rate and longer time period for decolorization [11]. For example, Datronia sp. KAPI0039 reached maximum $99.86 \%$ color reduction from $200 \mathrm{mg} \mathrm{L}^{-1}$ RBBR solution within only 72 hours of treatment, whereas maximum $98.87 \%$ decolorization from $1,000 \mathrm{mg} \mathrm{L}^{-1}$ RBBR solution was achieved after 168 hours of treatment (Figure 1). This was consistent with the study by Aksu et al. (2007) [18] that the white-rot T. versicolor took 8 days to reach maximum $95 \%$ color reduction from $58.4 \mathrm{mg} \mathrm{L}^{-1} \mathrm{RB} 5$ starting solution, whereas maximum $77 \%$ color reduction from $358.6 \mathrm{mg} \mathrm{L}^{-1} \mathrm{RB} 5$ starting solution was achieved within 14 days. Interestingly, RBBR seemed to be degraded much better than RB5 as observed by higher \%decolorization (Figures 1 and 2). Revankar and Lele [19] reported azo dyes were recalcitrant to decolorization and could be decolorized to a limited extent. However, Eichlerová et al. [20] stated that the difference between decolorization of structurally different dyes was

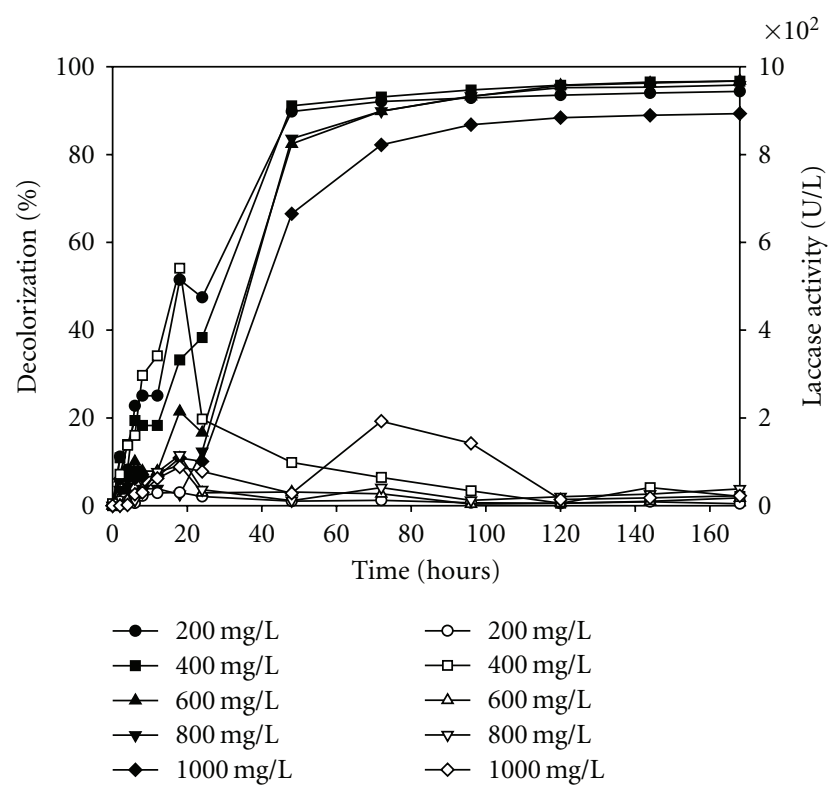

Figure 2: The effect of reactive RB5 dye concentrations on \%decolorization and Lac activity after cultivation with Datronia sp. KAPI0039; close symbol = \%decolorization; open symbol = Laccase activity.

not easy to explain. This was because that this process required the destruction of the chromophore, thus, the slow decolorization rate of some dyes could be attributed to the complexity of their chromophores, but the overall complexity alone was not an indicator of the difficulty of decolorization of a particular dye.

During the course of dye decolorization, maximum Lac activities at $759.81 \mathrm{UL}^{-1}$ and $178.57 \mathrm{UL}^{-1}$ were detected in the fungal-treated RBBR and RB5 solutions (Figures 1 and 2, respectively). A little $\mathrm{MnP}$ and none of LiP activities (data not shown) was detected. The results also indicated the corresponding increase in Lac activity with an increased $\%$ decolorization, with the enzyme activity peaking at the time of maximum color reduction (16-h cultivation). Thus, only Lac seemed to be correlated with the dye decolorization as also supported by Rodríguez study [1]. Moreover, the highest Lac activity and \%decolorization were obtained when $1,000 \mathrm{mg} \mathrm{L}^{-1}$ RBBR and RB5 solutions were applied. Thus, the higher dye concentration induced more Lac production and then resulting in more decolorization $[2,3]$. This could also imply that decolorization of reactive dyes partially depended on Lac activity in the liquid cultures, but not on $\mathrm{MnP}$ and LiP activities. In addition, Lac activity in the liquid culture with RBBR was also much higher than that with RB5 (Figures 1 and 2) even though the similar \%decolorization was observed. This could be associated with the specificity of ligninolytic enzymes on different dye structures [1], thus, different dye structures led to the induction of different ligninolytic enzymes. The important role of purified LiP in color reduction of several azo-, triphenyl methane, heterocyclic, and polymeric dyes has been clearly demonstrated $[1,11,21]$. In this experiment, 


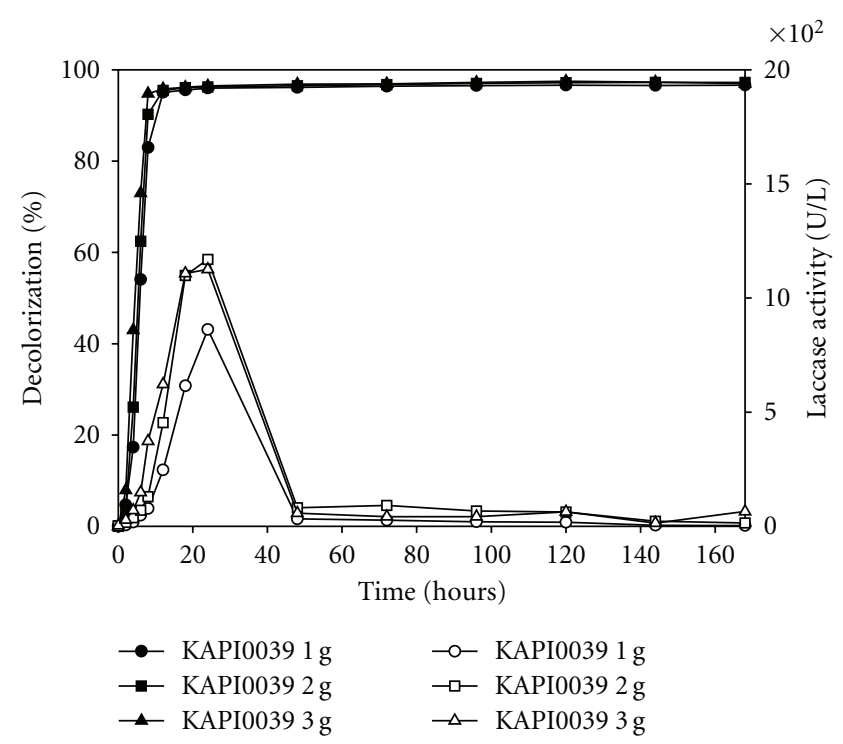

FIgURE 3: The effect of fungal inoculum size on \%decolorization of RBBR dye solution and Lac activity after cultivation with Datronia sp. KAPI0039; close symbol = \%decolorization; open symbol = Laccase activity.

none of LiP was detected, therefore, high \%decolorization of RB5 solution was thought to be involved in other mechanisms. One approach was attributed to the sorption of the dye on the fungal mycelium $[3,8]$. Thus, it could be assumed that the mechanism of synthetic dye degradation by Datronia sp. KAPI0039 was shared by the extracellular enzymes activity and biosorption on fungal cells. However, the relative contributions of ligninolytic enzymes to the decolorization of dyes might be different for each fungal strain and each dye [22].

3.2.2. The Effect of Fungal Inoculum Size. The effect of fungal inoculum size on \%decolorization, and $\mathrm{Lac}$ and $\mathrm{MnP}$ activities by Datronia sp. KAPI0039 was investigated (Figures 3 and 4). The inoculum sizes used in this study were varied at 1,2 , and $3 \%(\mathrm{w} / \mathrm{v})$. This strain decolorized both dyes tested, but RBBR decolorization was faster and started earlier than that of RB5. Over ninety percent of RBBR was decolorized as early as in the first 24 hours of cultivation, but only $20 \%$ of RB5 was removed within the same period and continuously removed to maximum $90 \%$ after 100 hours of cultivation. The fungal inoculum size was found to slightly affect the decolorization of both dyes. The production of Lac and $\mathrm{MnP}$ was also studied under the same conditions as in the decolorization experiments. The high activity of Lac was detected whereas low amount of MnP was detected. The results showed that Lac activity was affected partially by the fungal inoculum size as observed by the similar Lac activity in every fungal inoculum size used in the study. Usually, lower inoculum size requires longer time for the cells to multiply to sufficient number to utilize the substrate and produce enzyme. An increase in the inoculum size would ensure a rapid proliferation and biomass synthesis. However, after a certain limit, enzyme production could decrease because

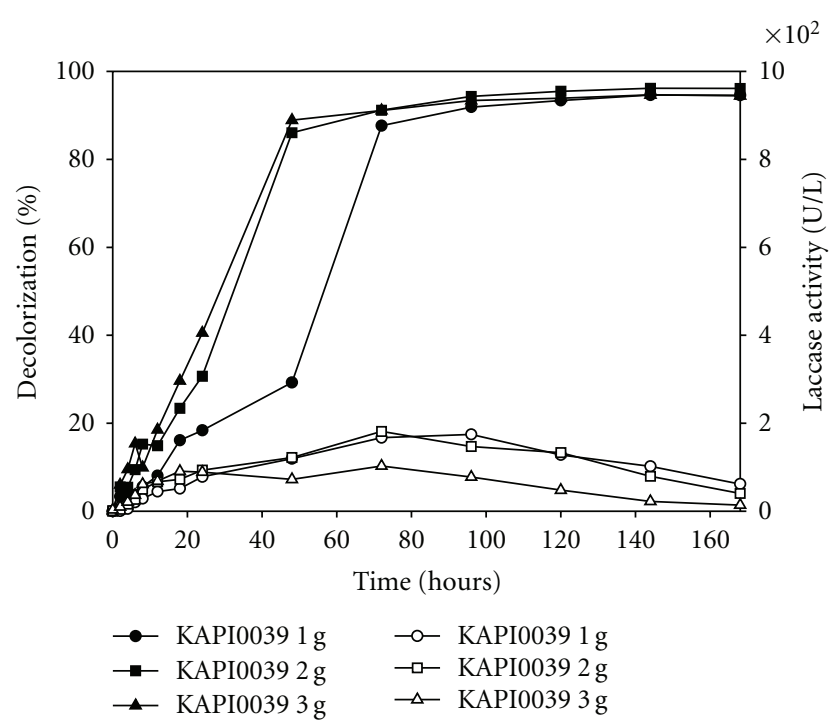

FIGURE 4: The effect of fungal inoculum size on \%decolorization of RB5 dye solution and Lac activity after cultivation with Datronia sp. KAPI0039; close symbol = \%decolorization; open symbol = Laccase activity.

of depletion of nutrients due to the enhanced biomass, which would result in a decrease in metabolic activity [23]. Furthermore, the results demonstrated direct relationship between Lac activity and dye decolorization as shown by the highest Lac activity and dye decolorization at the same period. The study of Baldrian and Šnajdr [3] was also consistent showing that RBBR was more efficiently degraded than RB5 by the litter-decomposing fungi, as well as that Lac was the major ligninolytic enzyme found in that condition.

3.2.3. The Effect of Reaction $p H$. The effect of $\mathrm{pH}$ on dye decolorization was investigated at $4 \mathrm{pH}(3,5,7$, and 9). The results were shown in Figures 5 and 6. Although the decolorization of individual dye (RBBR and RB5) was affected by $\mathrm{pH}$ to different extent, a better decolorization was observed for RBBR. The results also indicated that a better decolorization of RBBR was achieved under the neutral to basic conditions whereas RB5 was decolorized better under an acidic condition. This was consistent with the study by Young and $\mathrm{Yu}$ [11] that the azo-based dye was more effectively degraded by white-rot fungi under an acidic condition. During the decolorization experiment, the production of Lac and $\mathrm{MnP}$ by the fungus was determined as a function of time (Figures 5 and 6). Of the two enzymes studied, Lac activity was found in larger amount in the crude extract of both RBBR and RB5. The pH clearly affected Lac production (Figure 5). This is consistent with the research by Tavares et al. [24] that low $\mathrm{pH}$ values of the culture medium are not favorable for Lac production by Trametes versicolor. There could be 2 explanations for this: (1) either the metabolism of Lac synthesis is repressed at low $\mathrm{pH}$ values; or (2) conformational changes in the enzyme's threedimensional structure are promoted by low $\mathrm{pH}$, affecting the active site, not allowing biocatalytic reactions. Several 


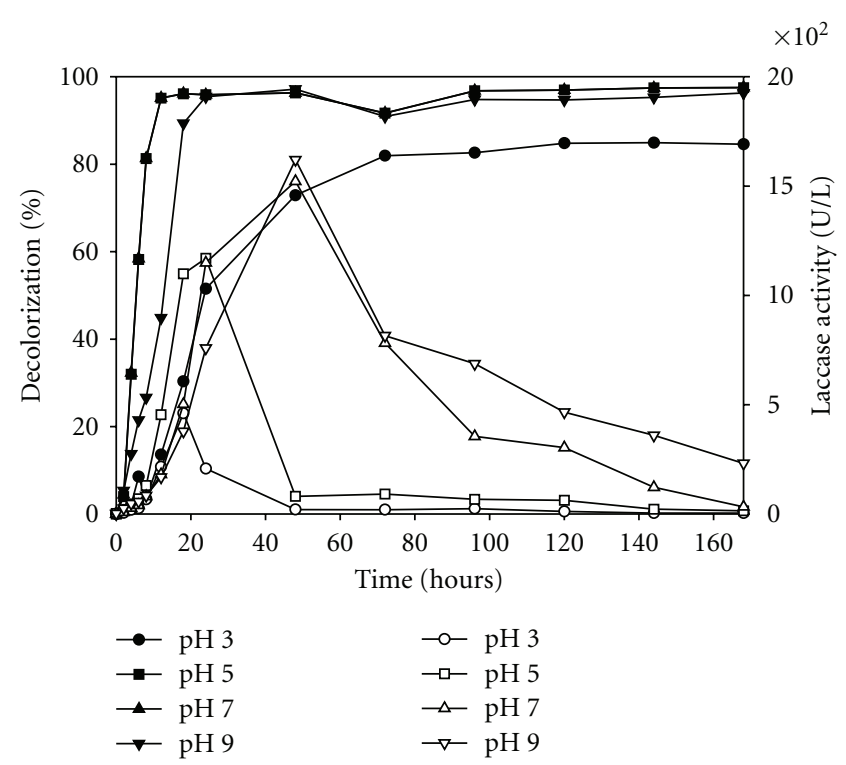

Figure 5: The effect of $\mathrm{pH}$ on \%decolorization of RBBR dye solution and Lac activity after cultivation with Datronia sp. KAPI0039; close symbol = \%decolorization; open symbol = Laccase activity.

studies also show that Lac stability was very dependent on $\mathrm{pH}$ and temperature. Nyanhongo et al. [25] reported that Lac stability from $T$. modesta was significantly affected by $\mathrm{pH}$ $<4.5$. Another study by Jönsson et al. [26] showed that $\mathrm{pH}$ less than 4 was detrimental for Lac production and suggested that a possible explanation for this was Lac's susceptibility to acidic proteases. Furthermore, the results indicated the relationship between time course of Lac production and the ability of Datronia sp. KAPI0039 to decolorize the two dyes.

\section{Conclusion}

Recently, there has been a growing interest in studying the lignin-degrading enzymes with the expectation to find more effective systems for the application in various biotechnological approaches. Previous studies demonstrated the presence of ligninolytic enzymes; Lac, MnP, and LiP; in several species of white-rot fungi, especially in P. chrysosporium and $T$. versicolor, but none has reported those enzymes in Genus Datronia. This is the first evident to report the decolorization capability and the production of ligninolytic enzymes, mainly Lac and MnP, by the Genus Datronia in the reactive dye solution. This study supports the different extent of fungal ability to degrade synthetic dyes of diverse structures. Although high concentration of dyes might have toxic effect on fungi, it was found that even a concentration of $1,000 \mathrm{mg} / \mathrm{L}$ of reactive dyes was tolerated by the tested specie. Interestingly, none was reported for the decolorization of such high dye concentrations by any white-rot fungi, except that studied by Eichlerová et al. [20]. This study suggests the possibility to decolorize a high concentration of commercial dyes. This could be a great advance in the treatment of dye-containing wastewater and the method may have a potential application for dye decolorization, especially

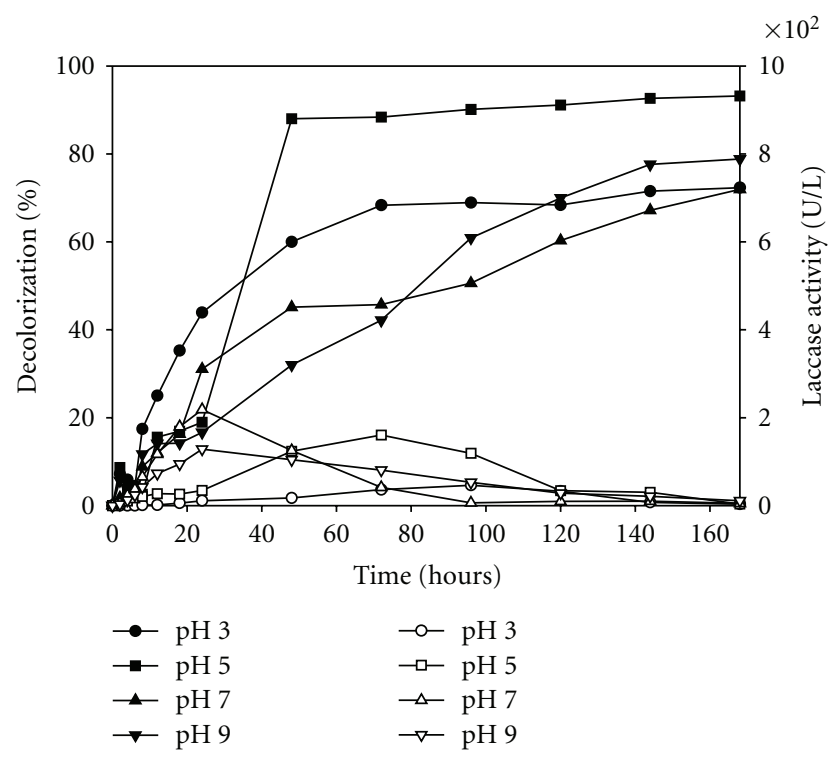

FIGURE 6: The effect of $\mathrm{pH}$ on \%decolorization of RB5 dye solution and Lac activity after cultivation with Datronia sp. KAPI0039; close symbol $=\%$ decolorization; open symbol $=$ Laccase activity.

in textile industry. The results also seem to indicate that Lac is the major ligninolytic enzymes involved in the breakdown of the dye in the solution. The crude extract from Datronia sp. KAPI0039 cultures showed the highest Lac activity and \%decolorization. Thus, Lac from Datronia sp. KAPI0039 will be purified and their kinetics constants determined with ABTS, RBBR, and RB5 as substrates in order to elucidate the specificity of Lac on these reactive dye structures. Moreover, the performance of Lac on decolorization reaction should be studied in vitro.

\section{Acknowledgments}

The authors would like to express sincere thanks to Kasetsart University Research and Development Institute (KURDI), Kasetsart University, and Thailand Research Fund (TRF) for financial support throughout the experiment.

\section{References}

[1] E. Rodríguez, M. A. Pickard, and R. Vazquez-Duhalt, "Industrial dye decolorization by laccases from ligninolytic fungi," Current Microbiology, vol. 38, no. 1, pp. 27-32, 1999.

[2] T. Robinson, B. Chandran, and P. Nigam, "Studies on the production of enzymes by white-rot fungi for the decolourisation of textile dyes," Enzyme and Microbial Technology, vol. 29, no. 8-9, pp. 575-579, 2001.

[3] P. Baldrian and J. Šnajdr, "Production of ligninolytic enzymes by litter-decomposing fungi and their ability to decolorize synthetic dyes," Enzyme and Microbial Technology, vol. 39, no. 5, pp. 1023-1029, 2006.

[4] T. W. Jeffries, S. Choi, and T. K. Kirk, "Nutritional regulation of lignin degradation in Phanerochaete chrysosporium," Applied and Environmental Microbiology, vol. 42, no. 2, pp. 290-296, 1981. 
[5] I. R. Hardin, H. Cao, S. S. Wilson, and D. E. Akin, "Decolorization of textile wastewater by selective fungi," Textile Chemist and Colorist and American Dyestuff Reporter, vol. 32, no. 11, pp. 38-42, 2000.

[6] I. Eichlerová, L. Homolka, L. Lisá, and F. Nerud, "Orange G and Remazol Brilliant Blue R decolorization by white rot fungi Dichomitus squalens, Ischnoderma resinosum and Pleurotus calyptratus," Chemosphere, vol. 60, no. 3, pp. 398-404, 2005.

[7] M. J. Lopez, M. D. C. Vargas-García, F. Suárez-Estrella, N. N. Nichols, B. S. Dien, and J. Moreno, "Lignocellulose-degrading enzymes produced by the ascomycete Coniochaeta ligniaria and related species: application for a lignocellulosic substrate treatment," Enzyme and Microbial Technology, vol. 40, no. 4, pp. 794-800, 2007.

[8] K. Svobodová, M. Senholdt, C. Novotný, and A. Rehorek, "Mechanism of reactive orange 16 degradation with the white rot fungus Irpex lacteus," Process Biochemistry, vol. 42, no. 9, pp. 1279-1284, 2007.

[9] N. Hiratsuka, M. Oyadomari, H. Shinohara, H. Tanaka, and H. Wariishi, "Metabolic mechanisms involved in hydroxylation reactions of diphenyl compounds by the lignindegrading basidiomycete Phanerochaete chrysosporium," Biochemical Engineering Journal, vol. 23, no. 3, pp. 241-246, 2005.

[10] S.-S. Shim and K. Kawamoto, "Enzyme production activity of Phanerochaete chrysosporium and degradation of pentachlorophenol in a bioreactor," Water Research, vol. 36, no. 18, pp. 4445-4454, 2002.

[11] L. Young and J. Yu, "Ligninase-catalysed decolorization of synthetic dyes," Water Research, vol. 31, no. 5, pp. 1187-1193, 1997.

[12] W. Apiwattanapiwat, P. Siriacha, and P. Vaithanomsat, "Screening of fungi for decolorization of wastewater from pulp and paper industry," Kasetsart Journal : Natural Science, vol. 40, no. 5, pp. 215-221, 2005.

[13] W. Apiwatanapiwat, W. Phochinda, T. Kreetachat, and P. Vaithanomsat, "Efficiency of ozone, activated carbon and microorganisms in decolorisation of pulp and paper mill effluent," Water Science and Technology, vol. 4, no. 2 .

[14] M. Tien and T. K. Kirk, "Lignin-degrading enzyme from Phanerochaete chrysosporium: purification, characterization, and catalytic properties of a unique $\mathrm{H}_{2} \mathrm{O}_{2}$-requiring oxygenase," Proceedings of the National Academy of Sciences, vol. 81, pp. 2280-2284, 1984.

[15] J. Chedchant, O. Petchoy, P. Vaithanomsat, W. Apiwatanapiwat, T. Kreetachat, and S. Chantranurak, "Decolorization of lignin-containing effluent by white-rot fungus Datronia sp. KAPI0039," in Proceedings of the 47th Kasetsart University Annual Conference, Bangkok, Thailand, 2009.

[16] J. Swamy and J. A. Ramsay, "The evaluation of white rot fungi in the decoloration of textile dyes," Enzyme and Microbial Technology, vol. 24, no. 3-4, pp. 130-137, 1999.

[17] H. Zouari-Mechichi, T. Mechichi, A. Dhouib, S. Sayadi, A. T. Martínez, and M. J. Martínez, "Laccase purification and characterization from Trametes trogii isolated in Tunisia: decolorization of textile dyes by the purified enzyme," Enzyme and Microbial Technology, vol. 39, pp. 141-148, 2006.

[18] Z. Aksu, N. K. Kilic, S. Ertugrul, and G. Donmez, "Inhibitory effects of chromium (VI) and Remazol Black B on chromium (VI) and dyestuff removals by Trametes versicolor," Enzyme and Microbial Technology, vol. 40, pp. 1167-1174, 2007.

[19] M. S. Revankar and S. S. Lele, "Synthetic dye decolorization by white rot fungus, Ganoderma sp. WR-1," Bioresource Technology, vol. 98, no. 4, pp. 775-780, 2007.
[20] I. Eichlerová, L. Homolka, and F. Nerud, "Synthetic dye decolorization capacity of white rot fungus Dichomitus squalens," Bioresource Technology, vol. 97, no. 16, pp. 2153-2159, 2006.

[21] P. Ollikka, K. Alhonmaki, V.-M. Leppanen, T. Glumoff, T. Raijola, and I. Suominen, "Decolorization of azo, triphenyl methane, heterocyclic, and polymeric dyes by lignin peroxidase isoenzymes from Phanerochaete chrysosporium," Applied and Environmental Microbiology, vol. 59, no. 12, pp. 40104016, 1993.

[22] C. Park, M. Lee, B. Lee et al., "Biodegradation and biosorption for decolorization of synthetic dyes by Funalia trogii," Biochemical Engineering Journal, vol. 36, no. 1, pp. 59-65, 2007.

[23] P. Kashyap, A. Sabu, A. Pandey, G. Szakacs, and C. R. Soccol, "Extra-cellular L-glutaminase production by Zygosaccharomyces rouxii under solid-state fermentation," Process Biochemistry, vol. 38, no. 3, pp. 307-312, 2002.

[24] A. P. M. Tavares, M. A. Z. Coelho, M. S. M. Agapito, J. A. P. Coutinho, and A. M. R. B. Xavier, "Optimization and modeling of laccase production by Trametes versicolor in a bioreactor using statistical experimental design," Applied Biochemistry and Biotechnology, vol. 134, no. 3, pp. 233-248, 2006.

[25] G. S. Nyanhongo, J. Gomes, G. Gübitz, R. Zvauya, J. S. Read, and W. Steiner, "Production of laccase by a newly isolated strain of Trametes modesta," Bioresource Technology, vol. 84, no. 3, pp. 259-263, 2002.

[26] L. J. Jönsson, M. Saloheimo, and M. Penttilä, "Laccase from the white-rot fungus Trametes versicolor: cDNA cloning of Icc1 and expression in Pichia pastoris," Current Genetics, vol. 32, no. 6, pp. 425-430, 1997. 

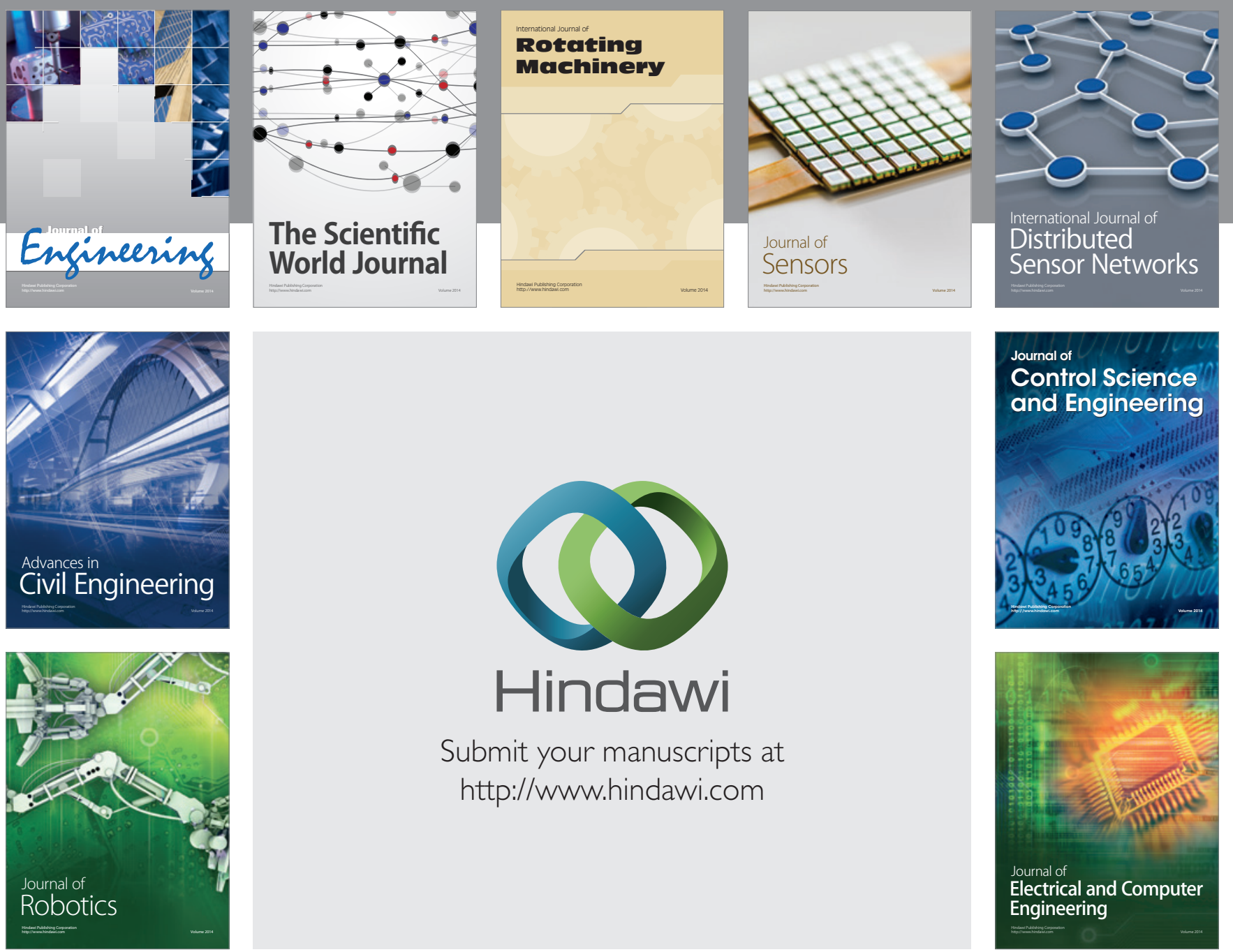

Submit your manuscripts at

http://www.hindawi.com
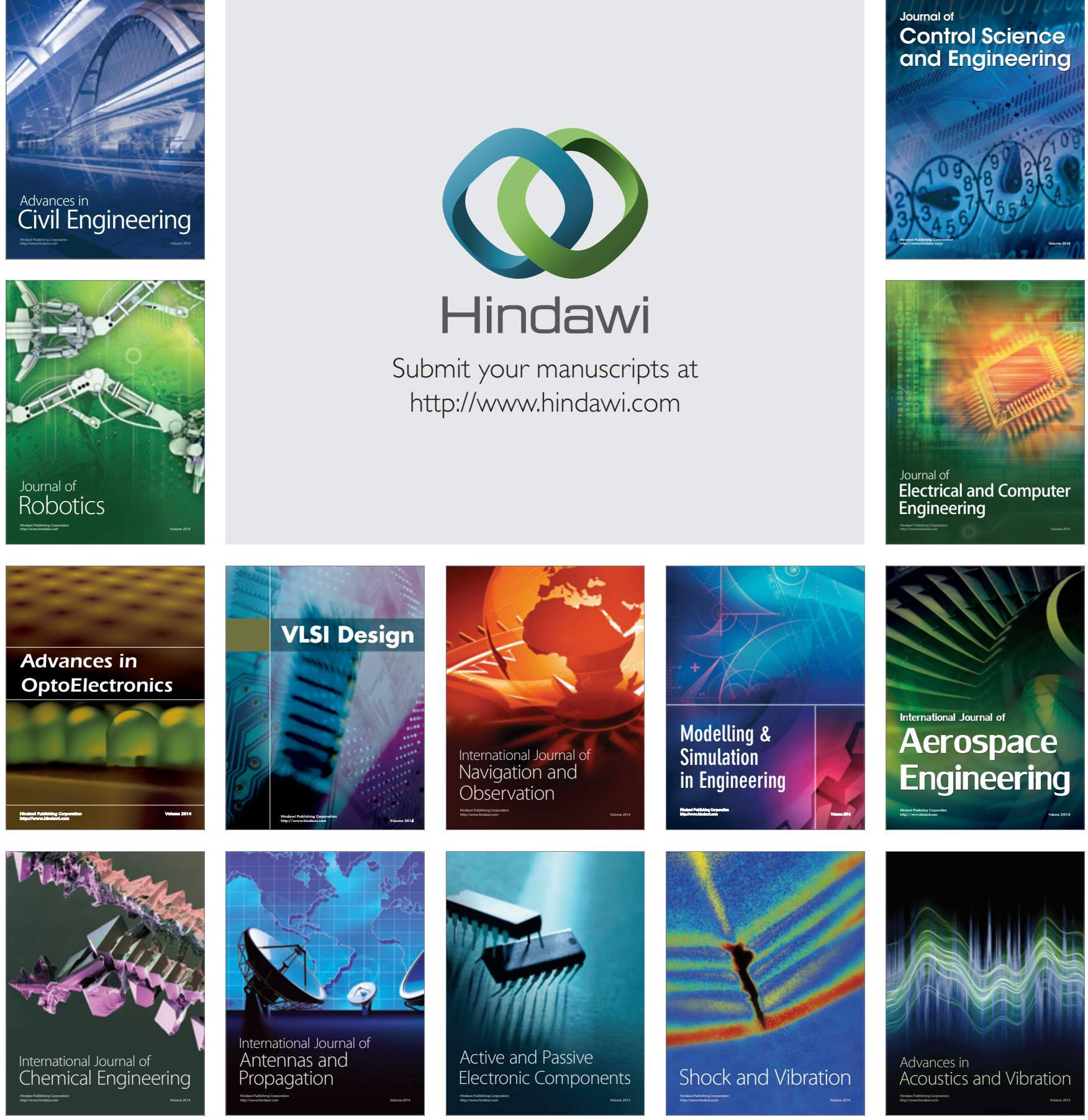